\title{
Landau-Kleffner syndrome
}

INSERM

\section{Source}

INSERM. (1999). Orphanet: an online rare disease and orphan drug data base. LandauKleffner syndrome. ORPHA:98818

Landau-Kleffner syndrome (LKS) is an age-related epileptic encephalopathy where developmental regression occurs mainly in the language domain and the electroencephalog raphic (EEG) abnormalities are mainly localized around the temporalparietal regions. The term acquired epileptic aphasia describes the main features of this condition. 